\title{
当科で施行した下肢切断術の検討
}

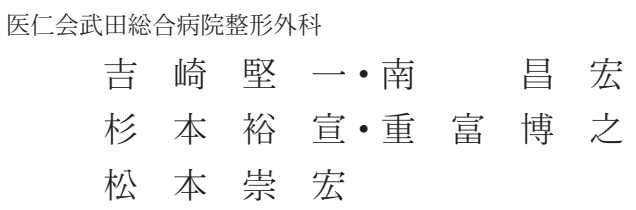

\section{Lower Limb Amputation at Our Hospital}

\author{
Kenichi Yoshizaki, Masahiro Minami, Hironobu Sugimoto, \\ Hiroyuki Shigetomi, and Takahiro Matsumoto \\ Department of Orthopedic Surgery, Takeda General Hospital, Kyoto, Japan
}

\begin{abstract}
We investigated 19 patients (13 males and 6 females) who had undergone major lower extremity amputation caused by arteriosclerosis (ASO), diabetes mellitus (DM), and chronic renal failure (CRF) from January 2001 through March 2005. The average age of the patients was 77.7 years. The average follow-up period was 10.1 months. We conducted an investigation into basic disease (ASO, DM, CRF), high cutting rank, surgical site infection, and prognosis. For the case that merged many basics diseases, survival rate was low regardless of a high cutting rank for one year, and surgical site infection worsened this rate.
\end{abstract}

Key words : amputation (切断), survival rate (生存率), complication（合併症）

\section{は じめに}

下肢切断術に㧍ける切断高位について様々な報告が なされているが，切断術後の患者における QOL の観 点に立ち，有害部を除き出来るだけ末梢で行うのが基 本的な考え方とする報告が多い。しかし可及的末梢で 切断することにより，切断端における創感染や断端部 壊死を併発し，中枢での再切断を余儀なくされる症例 あ存在する.今回我々は当科で行った下肢切断術にっ いて検討したので報告する.

\section{対象および調査項目}

平成 13 年 1 月から平成 17 年 3 月に施行した足趾切 断術を除いた下肢切断患者は 19 例であった。基礎疾 患の閉塞性動脈硬化症（以下 ASO）・糖尿病（以下 $\mathrm{DM}$ ）・慢性腎不全（以下 $\mathrm{CRF}$ ), 切断高位, 術後創
感染のおのおの之，予後について調査した。尚，切断 高位は下肢血管エコーで腓腹部の側副血行路の確認 （run-off の有無）で決定した.

\section{結果}

性別は男 13 例, 女 6 例, 手術時年齢は平均 77.7 歳, 術後経過観察期間は平均 10.1 ヶ であった。基礎疾 患の内訳として, ASO 単独 8 症例 (42\%), $\mathrm{ASO}+\mathrm{DM}$ and/or (•) CRF の合併 7 症例 (37\%), ASO を基礎疾患としない 4 症例（21\%）であった。 切断高位は下腿切断（以下 BK 切断） 3 例（16\%), 大腿切断（以下 $\mathrm{AK}$ 切断）14 例 (73\%), 股関節離断 （以下股離断） 2 例（11\%）であった。基礎疾患之 1 年生存率について, ASO 単独症例では 1 年生存率 75\%（6/8 例）であったが， $\mathrm{ASO}+\mathrm{DM} ・ \mathrm{CRF}$ 合併 症例では $14 \%$ （1/7 例）と予後不良であった。切断 
高位と 1 年生存率の関係は, BK 切断では $0 \%(0 / 3$ 例), $\mathrm{AK}$ 切断では 1 年生存率は $57 \%$ (8/14 例) であっ た（図 1 ）。通常予後良好とされる BK 切断症例にお いて当院では 1 年生存率は $0 \%$ となっていたが，その 詳細は術後 9 ヶ月と 4 ヶ月目に基礎疾患により突然死 した 2 症例之, 初回 BK 切断後 25 日目に AK 切断, またその 2 ヶ月後に股離断を施行した急速に壊死が進 行した症例であり, 全て $\mathrm{ASO}+\mathrm{DM} ・ \mathrm{CRF}$ 合併症例 であった．基礎疾患別の切断高位と 1 年生存率の関係
では, ASO 単独症例での AK 切断の 1 年生存率は 83\%（5/6 例）と最む良好であり， $\mathrm{ASO}+\mathrm{DM} ・ \mathrm{CRF}$ 合併症例は再切断を危惧して $\mathrm{AK}$ 切断を施行しても 1 年生存率は $25 \%$ （1/4 例）と予後不良であり，切 断高位による 1 年生存率に優位な差はなかった（図 2 ). 術後創感染については，19 例中 5 例（26\%）に術後 創感染を併発し，その全例術前血管エコー所見で腓腹 部での run-off は認めない症例に施行されており, そ の大部分に再切断術が追加施行されていた. AK 切断

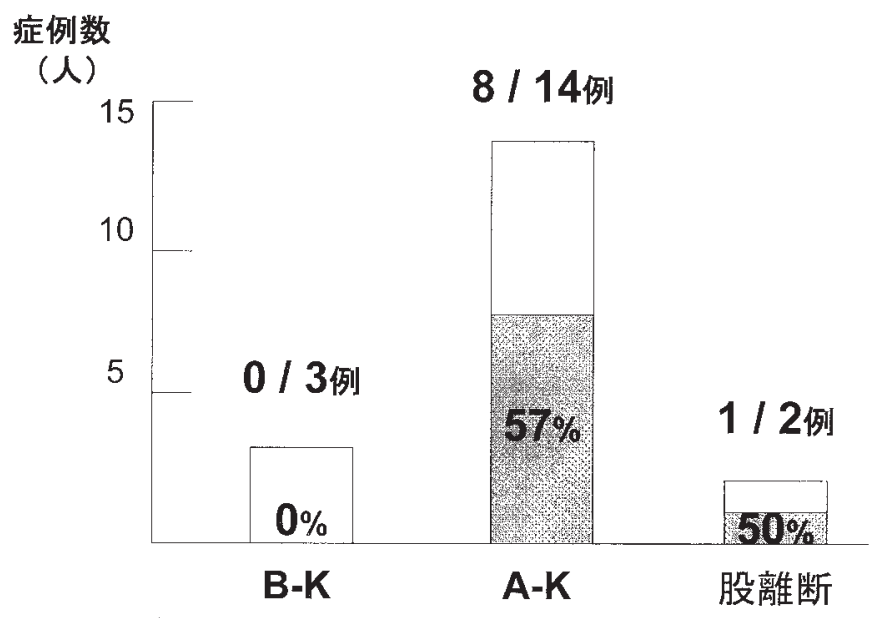

図 1 切断高位之 1 年生存率

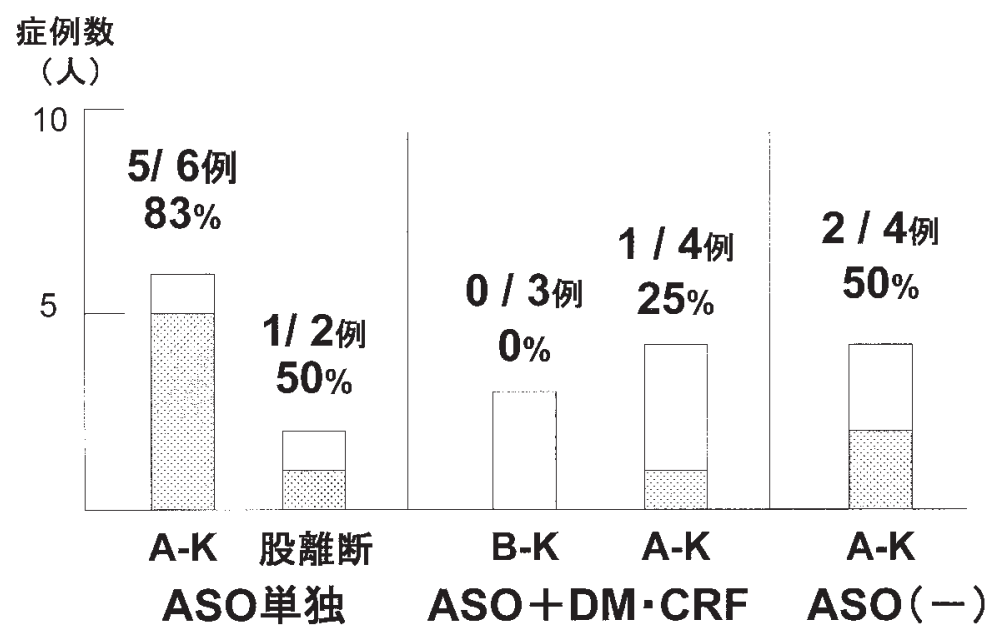

図 2 基礎疾患における切断高位と 1 年生存率の関係 
症例においては術後創感染が 14\%（2/14 例）と最む 低值であったが，股離断症例の 2 例は，ともに術後創 感染を併発していた。術後創感染を併発しなかった症 例の 1 年生存率は $57 \%$ （8/14 例）に対し, 併発した 症例の 1 年生存率は 20\%（1/5 例）と予後不良であ り, 術後創感染が 1 年生存率に大きく関与していると 考えられた。

考察

下肢壊死にて下肢切断を余儀なくされた症例の 1 年 生存率は Malone の報告では約 70\%とされている2). 当検討症例では $47 \%$ と低くなっているが，これは当 検討症例の平均年齢が 77 歳と諸家の報告と比べ高く, 多くの基礎疾患を合併している症例が多いことが原因 の 1 つと考えられる. 当検討症例では $\mathrm{ASO}+\mathrm{DM} ・$ $\mathrm{CRF}$ 合併症例に対し, $\mathrm{BK}$ 切断か $\mathrm{AK}$ 切断のよ゙ちら を施行しようとも予後不良であった。 下肢切断術にお ける術後創感染について網川らは約 $24 \%$ と報告して おり ${ }^{1)}$, 当検討症例でも術後創感染を併発したのは 26 $\%$ と同等だった。通常術後創感染を併発する症例は栄
養状態・既存感染の有無などの術前状態が良好でない ことが多く, 今回の検討の如く術後創感染併発の有無 が 1 年生存率に関与するとすれば，基礎疾患を多く合 併している症例では手術を一期的に終えるために，十 分に血流が保たれている中枢での切断術も考慮する心゙ きであるのではないかと考えられた。

結語

当科で施行した下肢切断術患者 19 例について検討 した，多くの基礎疾患を合併した症例では，切断高位 に関係なく 1 年生存率は低值であり，術後創感染が更 にそれを不良なむのとしていた。

\section{参 考 文 献}

1）網川慎一郎ほか：下肢切断一切断高位の再検討一. 東 日本整形外科災害外科学会誌, $15 ： 168-170,2003$.

2) Malone, J. M., Ballard, J. L. : Complications of lower extremity amputation. Complications in vascular surgery, pp.313-329. Edited by Bernhart, V. M., Towne, J. B., St. Louis, Quality Medical Publishing inc, 1991. 